\title{
Applying MERS for Induction Motor Driving
}

\author{
Miao-miao Cheng* Takanori Isobe* Shuhei Kato** \\ Kazuhiko Fukutani** Hideo Sumitani* Ryuichi Shimada*
}

\begin{abstract}
Squirrel cage induction motors are widely used as driven machine in industries due to low cost, robustness and simplicity. It is necessary to select a suitable driving method to satisfy their different practical applications. Focus on the motor applications which do not require variable speed operation, this paper presents a new circuit named MERS (Magnetic Energy Recovery Switch) for the motors driving. The driving characteristics are described both for steady state operation and the starting transient. Compared to the traditional Voltage Source Inverter with PWM control, MERS provides input power factor correction with simple phase angle control. Besides, line frequency switching makes the switch driving easier and soft switching reduces the switching loss greatly. With regard to the motor starting transient, soft-starting is realized based on the principle of reduced voltage starting. Another starting method is also proposed in this paper in order to improve the starting torque per ampere. MERS is potential for the induction motor driving.
\end{abstract}

Keywords : Input power factor correction, Motor driving, Loss reduction, Magnetic Energy Recovery Switch

\section{Introduction}

Induction motor driving asks for high energy efficiency responding to the energy saving movement and low carbon society construction. Voltage source inverter with PWM control comes to mind immediately at the mention of efficient induction motor driving. However, it is not the only solution, and not sufficient for some applications which do not require variable speed operation. VSI with PWM has disadvantages in low input power factor, hard switching and complicated control. Therefore, it is not a good cost-effective solution for the motor applications which do not require variable speed operation. Actually, even if it is used for motor soft-starting to avoid the mechanical and electrical strength on motor itself, it is often disconnected when motor steps into a normal operation area.

This paper proposes a new circuit named MERS (Magnetic Energy Recovery Switch) for the motors driving. The basic operation principle of MERS is a variable capacitor controlled by active switches. By connected in series to the power supply and motor load, MERS realizes terminal voltage control and improves input power factor. At first, the operation principle of MERS is described. Then, the improved performance of using MERS for motor driving is detailed for the steady-state operation. Then, focus on the starting transient, soft-starting is described based on a reduced voltage starting. Furthermore, another starting method

\footnotetext{
Research Laboratory for Nuclear Reactors, Tokyo Institute of Technology

2-12-1, O-okayma, Meguro, Tokyo, 152-8550

** Technical Development Bureau, Nippon Steel Co.,Ltd. 20-1, Shintomi, Futtsu 293-8511
}

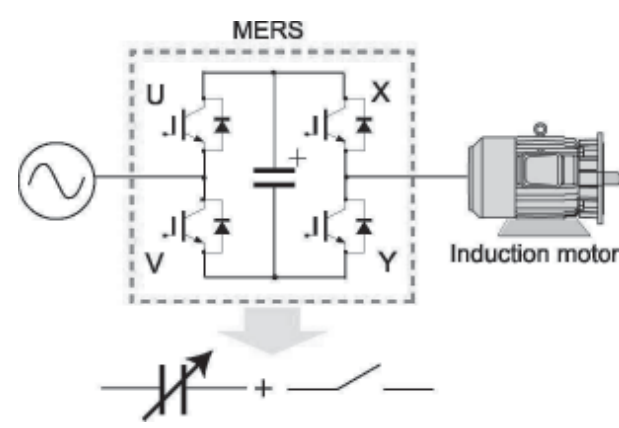

Fig.1 Configuration of motor driving using MERS

is presented so that the starting torque per ampere is improved. Finally, comparisons are performed between MERS circuit and VSI with PWM technology.

\section{MERS description}

$\langle 2 \cdot 1\rangle \quad$ Circuit configuration MERS is short for Magnetic Energy Recovery Switch [1]. It consists of 4 forced commutated switches, 4 diodes and a dc-capacitor. MERS is series connected between the power supply and the load, as shown in Fig.1. For three phase load, there will be one MERS for per phase. MERS is characterized of dc-capacitor, line frequency switching and phase angle control. By controlling the phase difference between the power supply and the switching, the capacitance inserted to the AC system changes from 0 to infinity. Therefore, MERS can be modeled as a variable capacitor plus on/off switch.

$\langle 2 \cdot 2\rangle \quad$ Variable capacitor principle As a basic operation, the switches of U-Y and V-X are operated in pairs and these two pairs operates in a complementary way. Therefore, the 


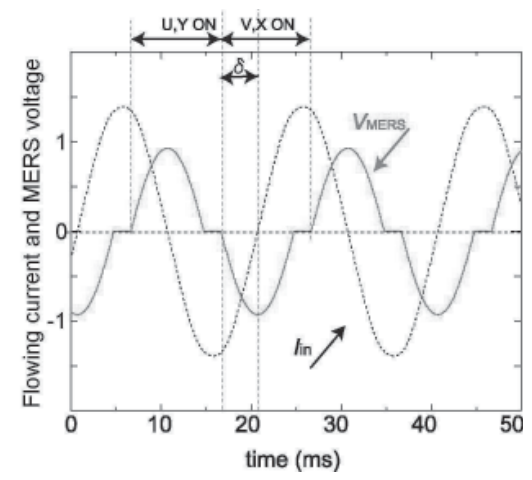

(a) Discontinues mode, $\left(\mathrm{X}_{\mathrm{MERS}}<\mathrm{X}_{\mathrm{C}}\right)$

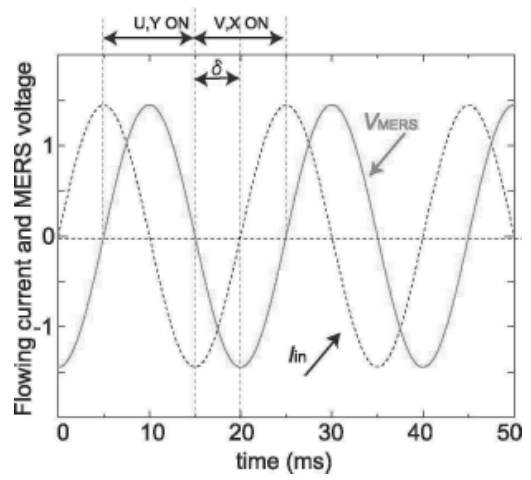

(b) Balance mode, $\left(\mathrm{X}_{\mathrm{MERS}}=\mathrm{X}_{\mathrm{C}}\right)$

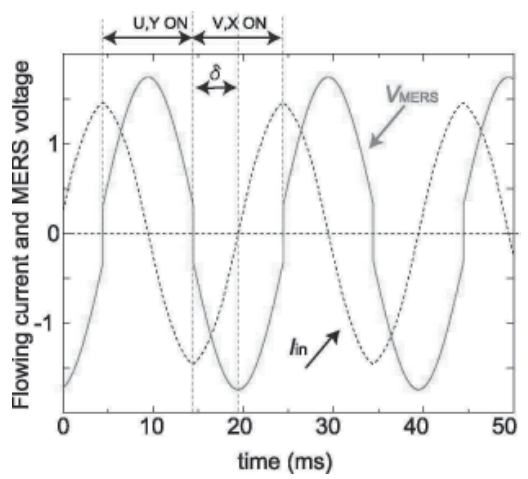

(c) Off-set mode, $\left(\mathrm{X}_{\mathrm{MERS}}>\mathrm{X}_{\mathrm{C}}\right)$

Fig.2 The three operation modes of MERS

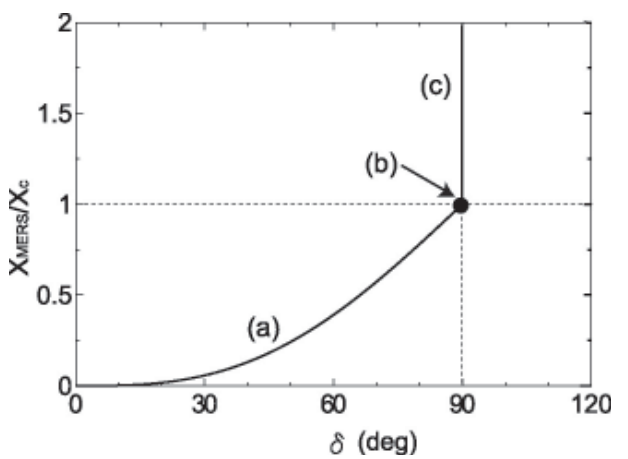

Fig.3 The equivalent capacitance of MERS changes with the phase angle $\delta$.

dc-capacitor is series inserted to the AC system with alternate polarity. The voltage generated on the dc-capacitor is controlled by the switching. The control object is the phase difference between the flowing current/power supply voltage and the switching. Describing the phase difference between the flowing current and the switching as $\delta$, three possible waveforms are generated as shown in Fig.2. MERS has three operation modes: a) discontinues mode. $X_{\text {MERS }}<X_{c}$. b) balance mode. $X_{\text {MERS }}=X_{c}$. c) dc-offset mode. $X_{\text {MERS }}>X_{c}$. Here, $X_{\text {MERS }}$ is the equivalent capacitance of MERS. $X_{c}$ is the actual capacitor equipped with the MERS.

The ratio of the equivalent capacitance which is injected by MERS to the equipped capacitor changes with the phase angle $\delta$ as shown in Fig.3. $\mathrm{X}_{\mathrm{MERS}}$ is changing from 0 to infinity. The three operation modes are also shown in Fig.3.

$\langle 2 \cdot 3\rangle$ Terminal voltage control The principle of MERS operating as a variable capacitor is clarified as above. In this part, MERS is applied to the motor driven and the modeled circuit is shown in Fig.4. In this circuit, motor is modeled as an inductive load with a power factor of $\cos \phi$. Assuming $\cos \phi=0.85$, terminal voltage as well as the reactive power supplied by MERS is calculated by changing the equivalent reactance of MERS.

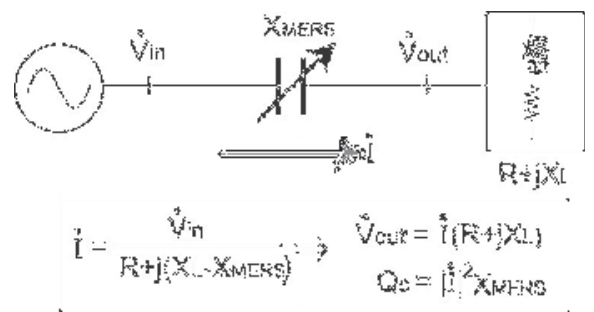

Fig.4 Model of series capacitor used in AC power system

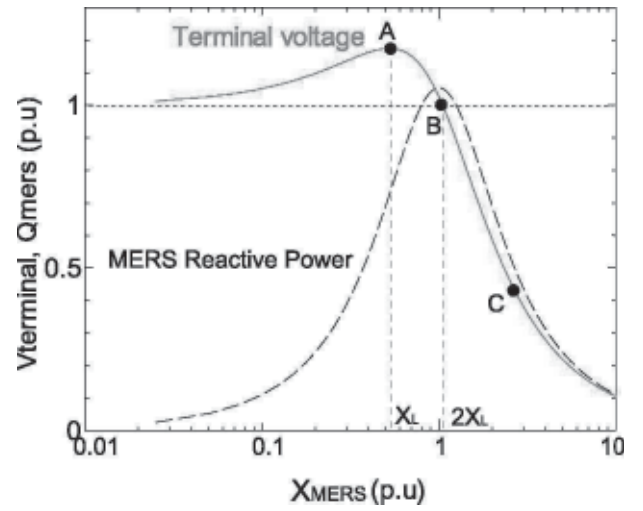

Fig.5 Terminal voltage/Reactive power compensation changing with the equivalent capacitance of MERS
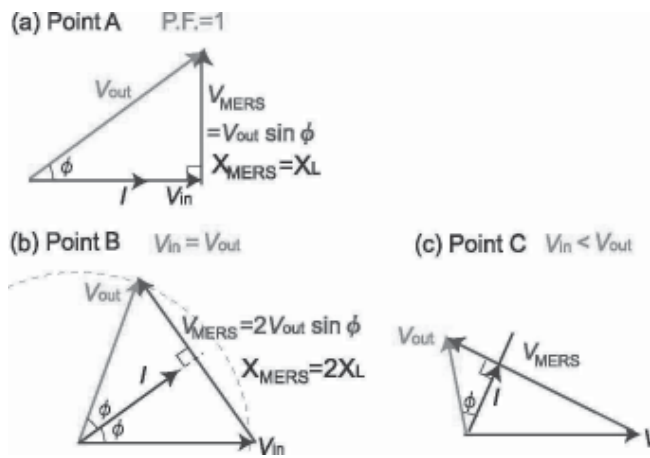

Fig.6 Phasor diagrams for the three cases. 
The calculation results are given as Fig.5. MERS can control the terminal voltage changing from 0 to a value higher than 1 p.u. With the reactive power of MERS changing, a lead, unity or lag power factor is realized for the power supply. There are several points should be taken attention to.

Point A: the maximum terminal voltage is achieved in this point. Here, the $X_{\text {MERS }}=X_{L}$. MERS supplies with the load reactive power completely. Power supply is with unity power factor. The maximum terminal voltage $\mathrm{V}_{\text {out }}=\mathrm{V}_{\text {in }} / \cos \phi$.

Point B: the terminal voltage is same to the power supply voltage. Here, the $X_{\text {MERS }}=2 X_{L}$. MERS supplies a reactive power twice of the load demand.

Point C: the terminal voltage is lower than the power supply voltage. This range is used for motor's soft-starting. A lead power factor is realized for the power supply.

The phasor diagrams for these three points are given in Fig.6. Especially, the relation of $\mathrm{X}_{\mathrm{MERS}}$ to the $\mathrm{X}_{\mathrm{L}}$ is explained by using phasor diagram.

3. Applying MERS for improving the motor's performance

$\langle 3 \cdot 1\rangle$ Input power factor correction As described in last section, Point A in Fig.5 realizes an unity power factor of the power supply. In order to operate at this point, the equivalent reactance of MERS is controlled to be equal to the load inductance component.

(1) Sizing the equipped capacitor Among the three operation modes, balance mode results in the least low order harmonics components in terminal voltage and

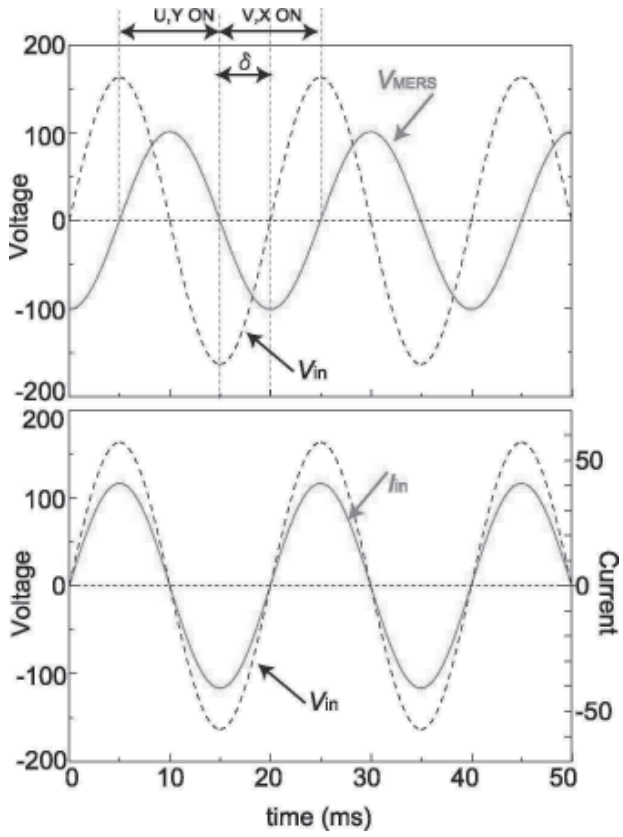

Fig.7 Simulation waveforms of balance mode in the case of unity input power factor. current. Therefore, the actual capacitor equipped for MERS is selected by the motor equivalent inductance component. Assuming the motor impedance in normal operation as $Z_{\text {rated }}$ and $\phi$ as the angle of power factor, then

$$
\mathrm{X}_{\mathrm{c}}=\mathrm{Z}_{\mathrm{rated}} \sin \phi
$$

(2) Fixing the control phase angle for achieving unity power factor. As described, in order to achieve a unity input power factor, the equivalent capacitance of MERS should equal to the load inductance. By selecting the actual capacitance equipped with the MERS equals to the load inductance, MERS is expected to operate at balance mode. Therefore, the phase angle $\delta$, which is the phase difference between the flowing current and the switching, should be fixed at 90 degree. It also suits for the dc-offset mode, which corresponds to the case of the actual equipped capacitance is smaller than the load inductance component ( $\mathrm{Xc}<\mathrm{Z}_{\text {rated }} \sin \phi$ ). With regard to the third operation mode, discontinues mode, the actual equipped capacitance is larger than the load inductance component. In order to achieve unity input power factor, the $\delta$ should be fixed at a quarter of the resonance cycle, which is determined by

$$
\delta=\frac{\pi}{2} \sqrt{L C}
$$

Here, $\mathrm{L}$ is the load inductance component, while $\mathrm{C}$ is the actual capacitor equipped for the MERS.

The input current and input voltage is in phase due to the unity power factor. Therefore, the $\delta$ also reflects the phase difference

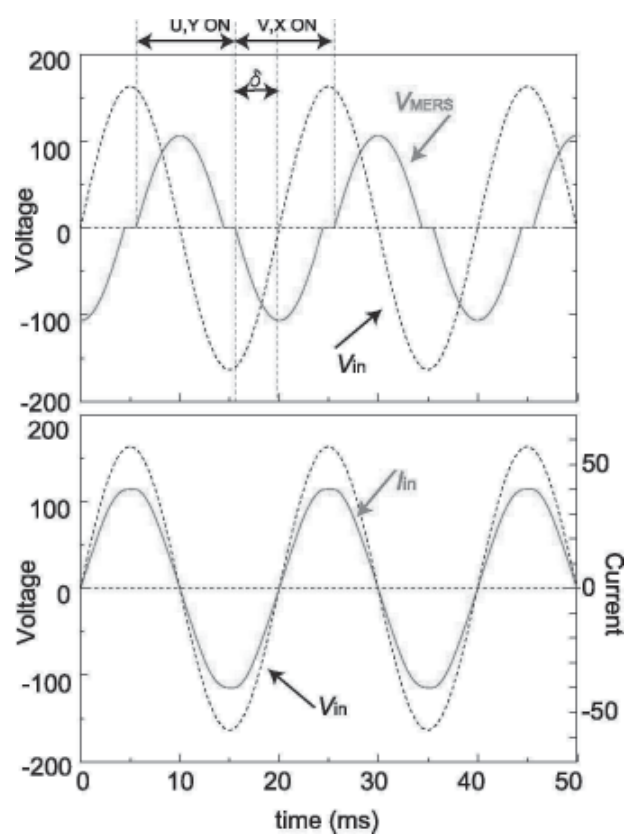

Fig.8 Simulation waveforms of discontinue mode in the case of unity input power factor. 
between the power supply and the switching. Fig.7 and Fig.8 shows the simulation waveforms of balance mode and discontinues mode respectively. By fixing the phase angle at 90 degree or a quarter of the resonance cycle respectively, both of them prove a unity input power factor

$\langle 3 \cdot 2\rangle$ Reduced motor loss at light load The induction motor losses mainly include copper losses, core losses, and mechanical loss. A balance between the copper loss and core loss is obtained at rated speed and rated load operation. However, this balance is lost at light load and results in a dramatically decreases of the motor efficiency. Copper loss decreases a lot at light load. However, the core loss is only determined by the stator voltage. As a solution, the stator voltage should be decreased to adjust the balance between copper loss and core loss as shown in Fig. 9. In the fact, there is only one value of stator voltage that operates the motor at optimum efficiency responding to the load conditions [2]. It is possible to be realized by using the terminal voltage control of MERS

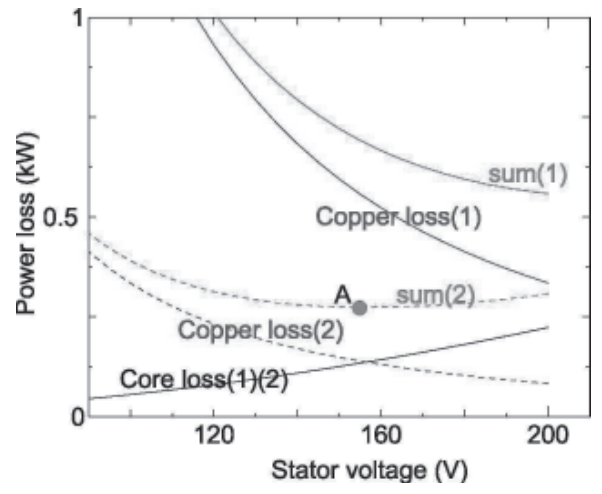

Fig.9 Power loss changes with the stator voltage under different loading conditions. Case1: rating load. Case2: 50\% load.

$\langle 3 \cdot 3\rangle$ Compact motor in the case of highly changing load torque As illustrated in Fig.5, MERS can increase the terminal voltage as high as $\mathrm{V}_{\text {out }}=\mathrm{V}_{\text {in }} / \cos \phi$. As well known, the motor generated torque increases with the square of the terminal voltage. A higher load torque is possible to be driven by the motor [3]. In the case of highly changing load, the required motor will be more compact.

4. Applying MERS for soft-starting the motors

$\langle 4 \cdot 1\rangle$ Motor soft-starting A rush current over than 6 times of the rated occurs when direct starting a motor in full voltage. Soft-starting is desired in order to avoid of the mechanical strength and electrical strength on the motor itself. The limited starting current is also benefit for the grid stabilization. MERS realizes motor soft-starting by reducing the terminal voltage. With the stator current as control target, the terminal voltage is increased gradually by phase angle control. It has been proven by a field experiment on $55-\mathrm{kW}$ pump motor in a factory.

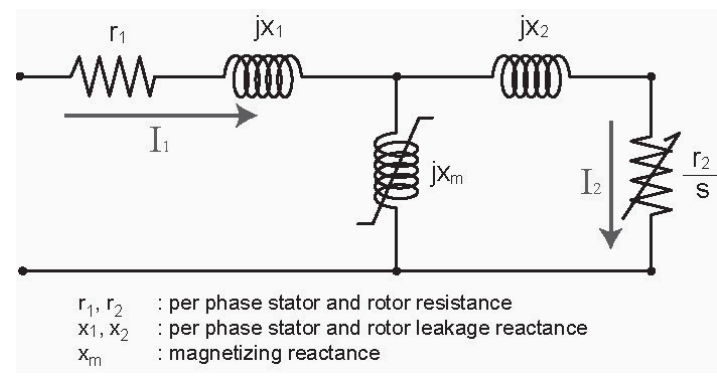

Fig.10 Equivalent circuit of induction machine

However, the basic principle of reduced voltage starting has determined that the starting torque is reduced greatly [4]. A centrifugal or square curve can be assumed for load torque in many cases. However, there are some applications where a high starting torque is required at low speeds. For example, screw compressors. The solution for these kinds of load is given in the following section.

$\langle 4 \cdot 2\rangle$ Low frequency starting Motor soft-starting by MERS has a disadvantage in a small starting torque. That is because the MERS can only control the terminal voltage while the frequency is kept constant. In order to get a high torque per ampere, both the terminal voltage and frequency should be adjustable [5]. Maintaining a fixed stator current $I_{1}$, the electromagnetic torque $T_{\mathrm{e}}$ is determined only by the frequency $f$ based on the equivalent circuit of Fig. 10 .

If assuming $k=3 \mathrm{r}_{2} \mathrm{p} /(2 \pi)$, the electromagnetic torque $T_{\mathrm{e}}$ is deduced as

$$
\begin{aligned}
& T_{e}=k \cdot \frac{I_{2}^{2}}{f \cdot s}=k \cdot \frac{\left(2 \pi L_{m}\right)^{2} \cdot I_{1}^{2}}{\frac{r_{2}^{2}}{f \cdot s}+\left[2 \pi\left(L_{m}+L_{2}\right)\right]^{2}(f \cdot s)} \ldots \ldots . .(1) \\
& T_{e_{\text {max }}}=k \cdot \frac{\left(2 \pi L_{m}\right)^{2} \cdot I_{1}^{2}}{2 r_{2}\left[2 \pi\left(L_{m}+L_{2}\right)\right]} \\
& f \cdot s=r_{2} /\left[2 \pi\left(L_{m}+L_{2}\right)\right] .
\end{aligned}
$$

Therefore, the maximal torque per ampere is fixed as shown in Eq.(2). The condition for developing the maximal torque per ampere is given as Eq.(3). At the instant of start-up transient, the starting torque is a function of the starting frequency by substituting the slip $\mathrm{s}=1$.

$\langle 4 \cdot 3\rangle$ Optimal starting frequency to achieving the maximum torque per ampere. A simulation is performed to show the relation of the starting torque per ampere to the starting frequency. The specifications of the simulated motor are given in Table 1. Using the Eq.(2) and Eq.(3), the maximal torque at rated current is $1.22 \mathrm{p} . \mathrm{u}$ and the optimal starting frequency is $1.24 \mathrm{~Hz}$.

The simulation results are shown in Fig.11. It is clear that the motor will develop a starting torque of more than 10 p.u with a start current of 3 p.u drawn when it is started at the optimal frequency. As shown in Fig.12, the experimental results confirm the calculation to a great extent. A little difference lies in the magnetizing saturation of induction motor. Fig.13 explains the influence of the magnetic saturation. In the saturation area, more 
Table 1: Specifications of the test motor

Stator Resistance, r1 $(\Omega)$

Rotor Resistance, $\mathrm{r} 2(\Omega)$

Stator Leakage Inductance, L1 $(\mathrm{mH}) \quad 11.4892$

Rotor Leakage Inductance, L2(mH) 11.4892

Magnetizing Inductance, $\mathrm{Lm}(\mathrm{mH}) \quad 169.422$

Rated current, I1(A)

Rated voltage, V1(V)

Poles, $\mathrm{p}$

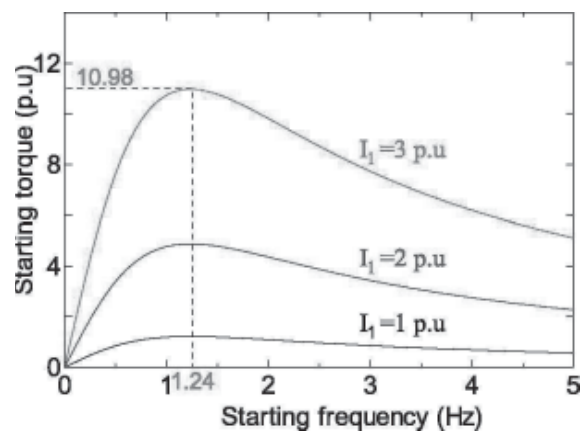

Fig.11 Simulation results on the starting torque-frequency

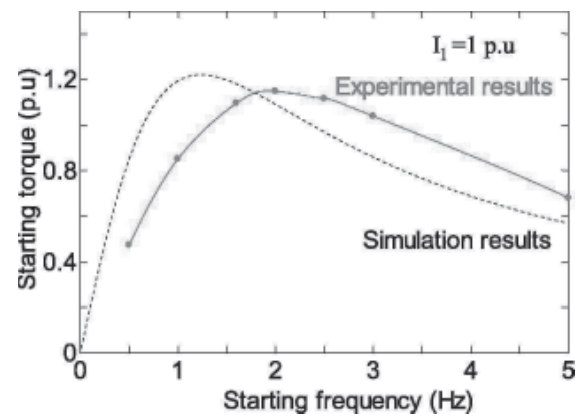

Fig.12 Comparison between the experimental results and simulation results

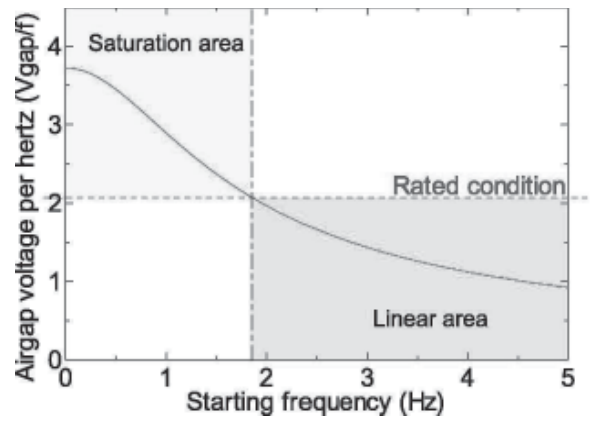

Fig.13 Illustration of magnetic saturation

current flows into the magnetizing windings due to a decrease of the magnetizing reactance $X_{\mathrm{m}}$, resulting in less rotor current and less torque developed.

$\langle 4 \cdot 4\rangle$ Switch-over configuration based on MERS As described above, variable frequency is desired in order to achieve a high torque per ampere during starting. In the fact, MERS has a

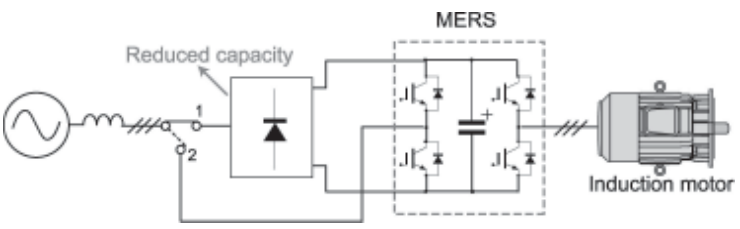

Fig.14 The switch-over configuration for developing a high torque per ampere during starting

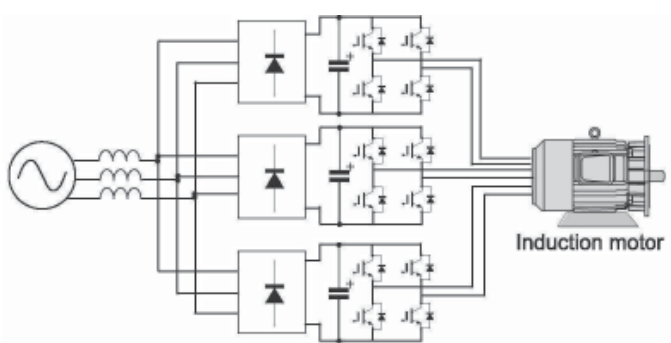

(a) When switch is tumed to 1

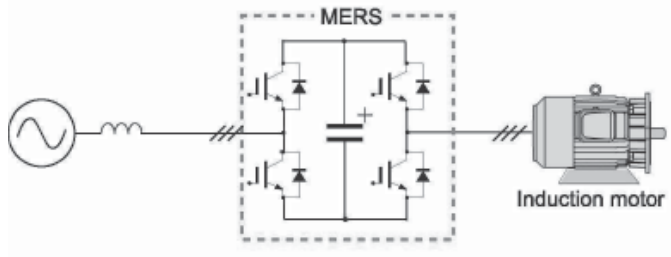

(b) When switch is turned to 2

Fig.15 Operation states of the switch-over configuration

similar configuration to full bridge inverter. By inserting rectifier into the AC circuit, a configuration which switches over the MERS circuit and VSI circuit is proposed as shown in Fig. 14

In this configuration, the switch is turned to position 1 firstly so that a VSI circuit is got. By operating the VSI to generate the optimal frequency, a high torque per ampere is achieved. When motor accelerates to a certain speed, the switch is turned to 2 and the configuration recovers to a basic MERS circuit. This method solves the problem of low starting torque when using MERS for soft-starting a motor. Besides, the capacity of the diode rectifier is small because it is only used at low speed range.

5. Comparison to the traditional VSI with PWM

$\langle 5 \cdot 1\rangle$ Loss calculation Some assumptions are made for the loss calculation on the traditional VSI with PWM and the MERS.

(1) Load condition is shown as Table 2.

Table 2 Rating of the three-phase induction motor used for loss calculation

$\begin{array}{lc}\text { Rated power } & 10 \mathrm{~kW} \\ \text { Rated voltage } & 200 \mathrm{~V} \\ \text { Rated current } & 34 \mathrm{~A} \\ \text { Rated frequency } & 50 \mathrm{~Hz} \\ \text { Power factor } & 0.85\end{array}$




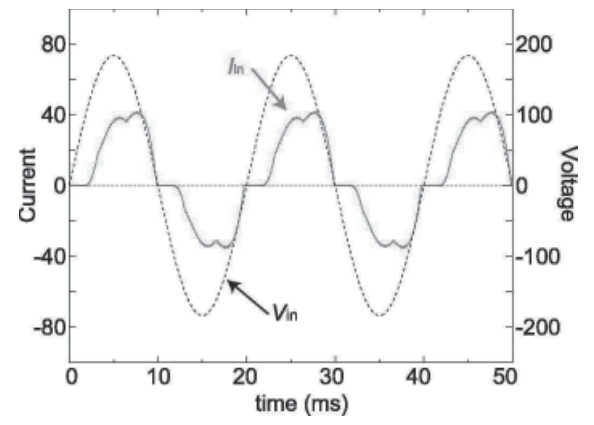

Fig.16 Input current and voltage in the case of VSI driven

(2) In the case of traditional VSI with PWM, inductance of $20 \%$ of the rating is inserted between the power supply and the diode rectifier. According to the simulation results, the input power factor is about 0.89 . The THD of the input current is about 0.24 . The input current and voltage curve is shown in Fig.16.

(3) $600 \mathrm{~V}$ class IGBTs and DIODE Rectifier is used for the loss calculation

The calculation results on the traditional VSI with PWM and the MERS are shown in Table 3. It is clear that MERS driven will reduce the switching loss because of the possible soft-switching. But the conduction loss increases due to the increasing necessary number of switches. Totally, MERS has a lower loss than the traditional VSI with PWM.

$\langle 5 \cdot 2\rangle$ Input power factor and THD As described before, the MERS can realize an unity power factor for the input power supply by controlling the phase angle of the switching. With regard to the THD of the input current, it is decreased to less than $1 \%$ by selecting a proper capacitor for MERS. MERS is controlled to operate at balanced mode under rated condition. When changing the terminal voltage, MERS shifts to DC-offset mode or discontinue mode. As shown in Fig.17, these two modes also have a very small THD of current.

In the case of traditional VSI with PWM, the input power factor changes with the series connected input inductance. So does the THD. Fig.16 shows the relationship between them. A larger series connected input inductance will decrease the distortion of current waveforms. However, the input power factor

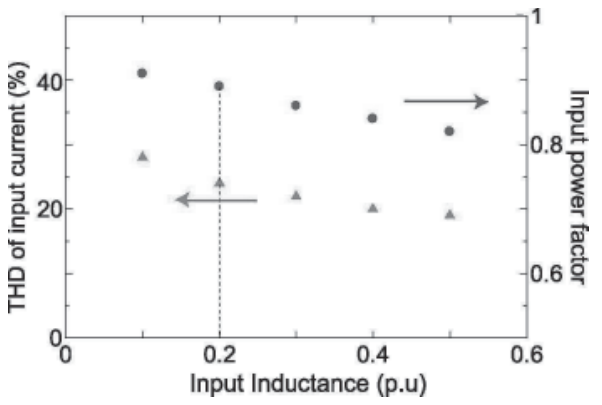

Fig.18 Input power factor and THD of input current in the case of VSI driven.

will decrease. The dotted line of Fig. 18 shows the simulated point in Fig.16.

\section{Conclusions}

MERS is proposed for motor control in this paper. Compared to the traditional VSI with PWM, MERS has advantages in high input power factor, low THD of input current, low loss with simple phase angle control and line frequency switching. It improves the motor performance in steady state. Also it realizes soft-starting for motors. With regard to the reduced starting torque during soft-starting, a switch-over configuration is also proposed to improve this problem.

\section{Reference}

[1] Takanori Isobe, Jan A. Wiik, F. Danang Wijaya, Kouta Inoue, Kazuhiro Usuki, Tadayuki Kitahara, Ryuichi Shimada : "Improved Performance of Induction Motor Using Magnetic Energy Recovery Switch”, PCC Nagoya 2007, 2-5 April 2007.

[2] Hussein Sarhan : "Energy Efficiency Control of Three Phase Induction Motor Drive", Energy and Power Engineering, pp: 107-112. 2011, 3

[3] Koji Kasuya, Takanori Isobe, Taku Takaku and Ryuichi Shimada: "Torque Enhancement of Induction Motor using Magnetic Energy Recovery Switch", The 2006 Annual Meeting of the Institute of Electrical Engineers of Japan, 15-17, March, 2006

[4] John Larabee, Brian Pellegrino, Benjamin Flick : "Induction Motor Starting Methods and Issues", Petroleum and Chemical Industry Conference, 2005.

[5] Miao-miao Cheng, Takanori Isobe, Shuhei Kato, Kazuhiko Fukutani, Hideo Sumitani and Ryuichi Shimada: "An Innovative Method for Induction Motor Driving Using Magnetic Energy Recovery Switch (MERS) ", PCIM Asia 2011(International Exhibition \& Conference for Power Electronic Intelligent Motion Power Quality ), June 21-23, 2011, China

Table 3. Loss comparison between the traditional VSI with PWM and the MERS The traditional VSI with PWM MERS

$\begin{array}{lcc}\text { DIODE Rectifier } & 42 \mathrm{~W} & 0 \\ \text { IGBT conduction loss } & 16.8 \times 6 \mathrm{~W} & 7.3 \times 12 \mathrm{~W} \\ \text { DIODE conduction loss } & 2.6 \times 6 \mathrm{~W} & 6.5 \times 12 \mathrm{~W} \\ \text { Switching loss, with switching frequency of } 10 \mathrm{kHz} & \\ \text { Turn-on, Eon } & 10.9 \times 6 \mathrm{~W} & 0 \\ \text { Turn-ff, Eoff } & 5.1 \times 6 \mathrm{~W} & 0 \\ \text { Recovery, Err } & 2.4 \times 6 \mathrm{~W} & 0 \\ \text { Sum } & 268.8 \mathrm{~W} & 165.6 \mathrm{~W}\end{array}$

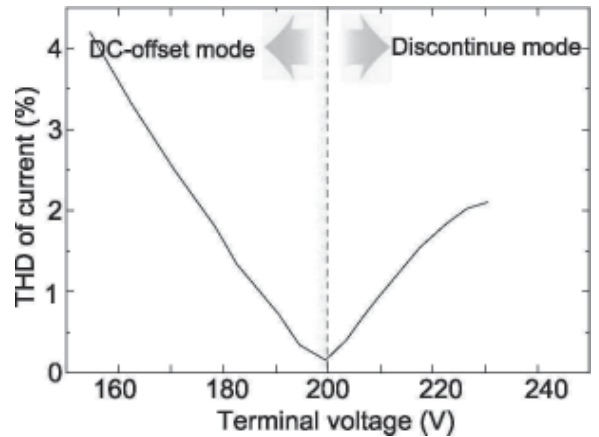

Fig.17 THD of the three operation modes of MERS 


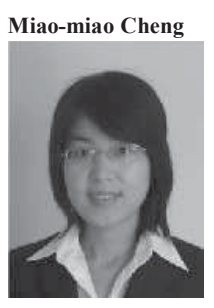

was born in 1982, China. She received the M.Sc.degree at Xi'an Jiaotong University in July, 2006. Then, she received the $\mathrm{Ph} . \mathrm{D}$ degree in Tokyo Institute of Technology in Sep.,2009, where she is working as a postdoctoral researcher. Her research interests are in the area of motor control, energy storage and power electronics.

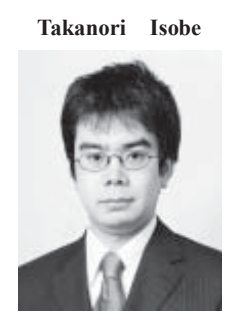

was born in 1978. He received the Ph.D degree in Mar. 2008 from Tokyo Institute of Technology. From 2008 to 2010 , he was a researcher of Tokyo Institute of Technology. Then from 2010, he became an assistant professor of Research Laboratory for Nuclear Reactors. His research interests are in the area of soft-switching power converters.

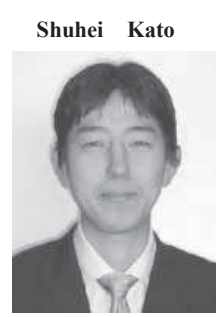

was born in 1981. He received the M.Sc.degree and Ph.D degree in Mar. 2006 and Mar. 2009 respectively from Tokyo Institute of Technology. From 2009 to 2011, he was a researcher of Nippon Steel Corporation. Now, he is working in SMACH Corporation. His research interests are in in the area of flywheel energy storage system, motor control and power electronics.

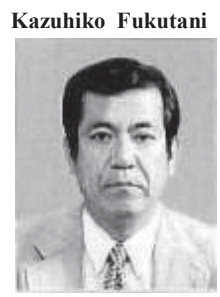

was born in 1953. He received the M.sc degree of Engineering in electrical engineering from Tokyo Institute of Technology in 1979. Then, he joined in the Nippon Steel Corporation. Till 1997, he was involved in the development of electrical instrumental equipment. Then, he was in charge of the development of system control technology till now. From 2005, He was appointed as professor of Tokyo Institute of Technology.

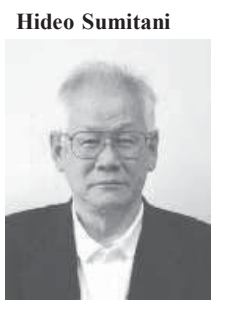

was born in 1935. He graduated from Tokyo Institute of Technology in 1959, and joined Toshiba Corp., where he was involved in development of industrial AC electric rotating machinery. He transferred to Toshiba Technical Service International Corporation in 2001, and was appointed a part-time professor of the Tokyo Institute of Technology in the same year.

Ryuichi Shimada

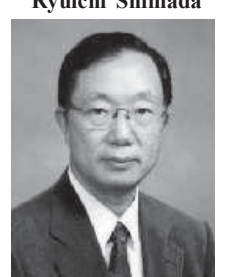

was born in Tochigi, Japan. He received the Doctor degree of Engineering in electrical engineering from Tokyo Institute of Technology, Tokyo, Japan in 1975. From 1975 to 1988 , he was a researcher of Nuclear Fusion development and an Electrical Engineer at the Japan Atomic Energy Research Institute, Tokai-mura, Ibaraki, Japan. In 1988 he became an associate professor of Department of Electrical and Electronics Engineering at Tokyo Institute of Technology, Tokyo, Japan. In 1990, he became a professor and joined the Research Laboratory for Nuclear Reactors, Tokyo Institute of Technology where he is currently with the Department of Energy Science. Prof. Shimada has received the 1985 Outstanding Achievement Award, the 1976 and 2000 Outstanding Paper Award from IEE of Japan. Recently, he has received the 2003 Excellent Published Book Award from IEE of Japan.

\section{【質疑】 \\ ヤンマー（株）・茂木進一氏}

【質問 1】 MERS に用いるコンデンサの容量（F）の決め 方は?

【回答 1】 MERS の発生させる等価リアクタンスと実際 に設置してあるコンデンサのリアクタンスの関係によって MERS の波形モードが決まる。一方、ほかの二つの波形モ ードと比べて、バランスモードにおいて端子電圧や端子電 流の高調波歪み率は一番小さいである。したがって、定常 動作時にバランスモードになるように、補償したいリアク タンスと一致したコンデンサの容量を決めればよい。

【質問 2】MERS に用いるコンデンサの種類は何を使って いるのか?何かの制約はありますか?

【回答 2】MERS に用いるコンデンサの両端に発生する 電圧が DC 電圧であり、IGBT などスイッチの切り替えによ って交流回路に直列に挿入する。したがって、電解コンデ ンサやセラミックコンデンサやどちらでも使用可能であ る。

【質問 3 】Fig.15(a)の回路において、定常時 Fig.15(b)で選定 したコンデンサをそのまま使用することは問題があったり しないのでしょうか?

【回答 3】定常時 Fig.15(b)で選定したコンデンサは大体 定格容量の半サイクルから 1 サイクルのエネルギーがため られます。一方、電圧型インバータでは、電圧リップルを 防ぐためDC リンクコンデンサがおよそ1サイクルのエネル ギーをためています。しかし、Fig.15(a)の回路は起動におい ての低速度時だけの使用になるし、定格電流起動において 起動時の有効電力は定格容量より小さいので、定常時 Fig.15(b)で選定したコンデンサをそのまま使用しても問題 がないと言える。 